\title{
A decline in language rights violation complaints received by PanSALB - The case of Afrikaans
}

\author{
Marné Pienaar \\ University of Johannesburg, Auckland Park Kingsway Campus, P.O. Box 524, Auckland Park, 2006 \\ mpienaar@uj.ac.za
}

\section{Introduction}

Since 2002 the Pan South African Language Board (PanSALB) has experienced a decline in the number of complaints received concerning alleged language rights violations. An investigation into the nature of and reasons for this decline showed that the decline can largely be attributed to the fact that the Afrikaans speech community no longer lodges complaints with PanSALB. This paper reports on the reasons for this decline. It is argued that this particular community has turned away from PanSALB and now rather engages in other strategies in order to overcome the perceived marginalisation of Afrikaans. However, what at first glance appears to be a case of language planning from the bottom rather than from the top, is complicated by the social and financial capital of this speech community.

\section{A decline in language rights violation complaints received by PanSALB}

The findings presented in this paper are based on a study conducted in 2007 into the reasons for the decline in language rights violation complaints received by PanSALB. The methodology entailed a literature review concerning PanSALB and language rights violation complaints in South Africa, as well as a document-based investigation involving an in-depth 
qualitative analysis of the approximately 400 complaints lodged with PanSALB over the tenyear period of 1997 to 2007.

\subsection{Overall trends in the data set}

The composite data set covers ten financial years, from 1 April 1997 to 31 March 2007. The graph in figure 1 represents the complete data set and captures the trends that emerged from the complaints lodged. The graph shows that in the first financial year 1997-1998, only a single complaint was lodged. 1998-1999 saw an increase to 21 complaints, and an increase by almost the same margin in 1999-2000. This steady increase continued in the period 20002001, with a total of 74 recorded cases. In 2001-2002 there was a slight drop, followed by the all time high of 2002-2003, peaking at 100 complaints. This gradual increase stands in sharp contrast to the rapid drop from 100 to 23 in 2003-2004, a decrease of $77 \%$. The slight increase in 2004-2005 was countered by the decline in the last two years of 18 and 15 complaints, respectively.

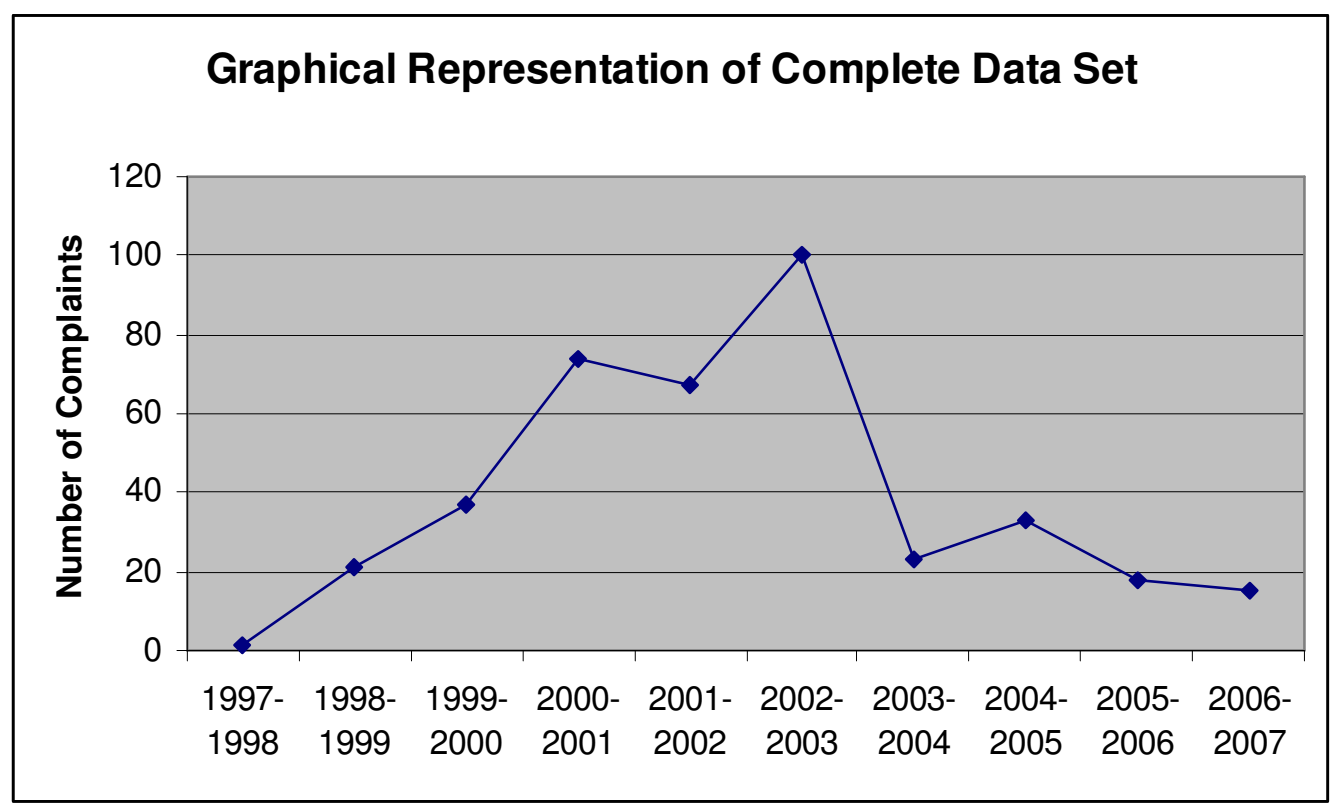

Figure 1. The composite data set 1 April 1997 - 31 March 2007

\subsection{Pro-Afrikaans complaints}

Pro-Afrikaans complaints were observed to comprise the bulk of the complaints and were isolated from the rest of the data set. Through such isolation, the pro-Afrikaans complaints were made distinct from complaints relating to African languages, and the "other" complaints, 
where "other" refers to complaints that cannot be neatly classified according to the preference for a specific language/language choice. Broadly speaking, "other" complaints are in favour of multilingualism. The isolation of pro-Afrikaans complaints allowed for an examination of whether there was indeed a decline in the number of complaints in this category. Figure 2 shows the trends in the lodging of pro-Afrikaans complaints over the ten year period. There was a steady rise in the number of complaints between 1997 and 2000. A sharp rise followed in the period 200-2001, followed by a marginal drop in 2001-2002. Another sharp rise occurred in the period 2002-2003, peaking at 73, the highest number of pro-Afrikaans complaints. This peak stands in sharp contrast to the steep drop in 2003-2004 - a drop from 73 to 17 , translating to a drop by $82 \%$. This drop was followed by a marginal rise in 20042005, a subsequent decline in 2005-2006 and a negligible rise in 2006-2007. This trend so closely approximates the graph for the overall data set as to be almost a replica of it (cf. figure 1). This replication reveals the significant impact of pro-Afrikaans complaints on the data set as a whole. The peaks and troughs are almost identical and occur at the matching time periods.

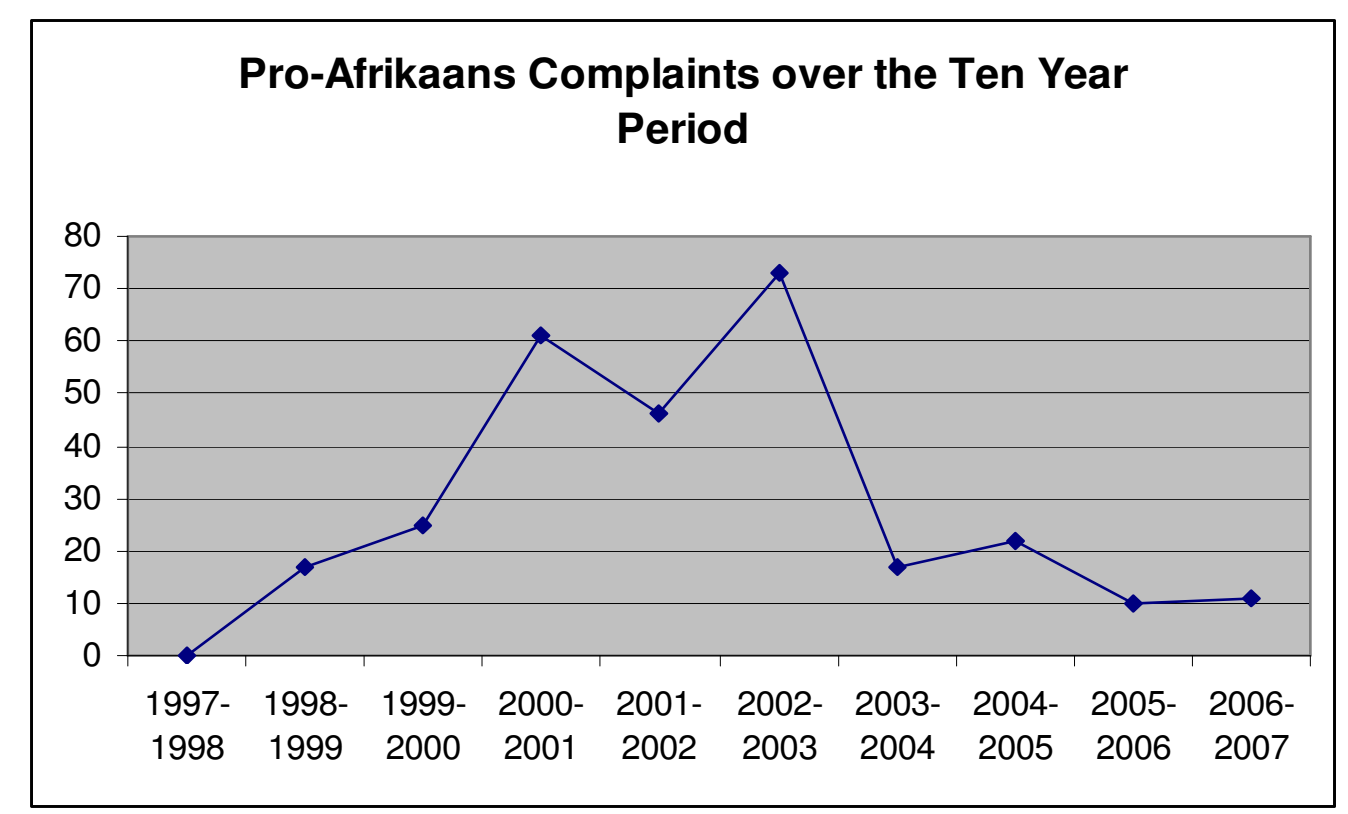

Figure 2. Pro-Afrikaans complaints over the ten-year period

\subsection{Group complaints}

The rationale for analysing the data according to groups is to provide information on groups that were lodging complaints, to ascertain the frequency of complaining groups (how many 
times each group complained), and to see whether or not groups remained consistent in raising language complaints during the ten year period. Table 1 below shows the names of organisations that complained, the number of complaints of each, and the spread of these complaints over the ten years.

\begin{tabular}{|c|c|c|c|}
\hline & Group & Number of complaints & Year(s) complaints lodged \\
\hline 1. & Freedom Front & 5 & $\begin{array}{l}1998-1999,1999-2000 \\
\text { 2001-2002, 2002-2003 }\end{array}$ \\
\hline 2. & Vriende van Afrikaans & 3 & $\begin{array}{c}\text { 1998-1999, 2005-2006, } \\
2006-2007\end{array}$ \\
\hline 3. & Suid-Afrikaanse Kommunikasie-unie & 1 & 1998-1999 \\
\hline 4. & Freedom of Expression Institute & 1 & 1998-1999 \\
\hline 5. & Northern AmaNdebele Organisation & 2 & 1999-2000, 2005-2006 \\
\hline 6. & Naamaican Judicial Board & 1 & $1999-2000$ \\
\hline 7. & Mine Workers Union & 9 & 1999-2000, 2000-2001 \\
\hline 8. & Afrikanerklub & 2 & 1999-2000, 2006-2007 \\
\hline 9. & Afrikanerbond & 2 & 1999-2000, 2001-2002 \\
\hline 10. & Radio Pretoria & 1 & $1999-2000$ \\
\hline 11. & Dusk Dimensions & 1 & $2000-2001$ \\
\hline 12. & Pro-Afrikaanse Aksiegroep (PRAAG) & 2 & 2000-2001, 2003-2004 \\
\hline 13. & Afrikaanse Taal- en Kultuurvereniging (ATKV) & 1 & $2000-2001$ \\
\hline 14. & SAPS Frankfort & 1 & $2000-2001$ \\
\hline 15. & Community Council Petersburg & 2 & $2001-202,2002-2003$ \\
\hline 16. & Public Protector & 1 & 2003-2004 \\
\hline 17. & Solidarity Union & 1 & $2004-2005$ \\
\hline 18. & Mendes et al & 1 & $2004-2005$ \\
\hline 19. & Krugersdorp Distrikslandbou-unie & 1 & $2004-2005$ \\
\hline 20. & Democratic Alliance & 1 & $2005-2006$ \\
\hline 21. & Congregation of the Oratory of the Order of St Philip Neri & 1 & $2005-2006$ \\
\hline 22. & Vereniging van Regslui van Afrikaans & 1 & $2005-2006$ \\
\hline 23. & The Genootskap vir die Handhawing van Afrikaans & 1 & $2005-2006$ \\
\hline \multirow[t]{2}{*}{24.} & Concerned Commuters Forum & 1 & $2006-2007$ \\
\hline & Total & 42 & \\
\hline
\end{tabular}

Table 1. Group complainants

As the bulk of complaints in the group category were launched by pro-Afrikaans organisations, it is necessary to examine the impact of pro-Afrikaans groups on the proAfrikaans data set, as well as on the overall data set. An assumption would be that the number of groups lodging complaints would correspond with the patterns of increase demonstrated in the pro-Afrikaans and overall data sets. The graph in figure 3 shows a consistent rise in the number of pro-Afrikaans groups lodging complaints between 1997 and 2000, from one to five groups. There was however, a consistent decline between 2001 and 2004, with only one group lodging a complaint in the period 2003-2004. A marginal increase took place in the subsequent year, 2004-2005, followed by a sharp rise in 2005-2006. Finally, there was a noticeable decline in 2006-2007, with only two groups lodging complaints. 


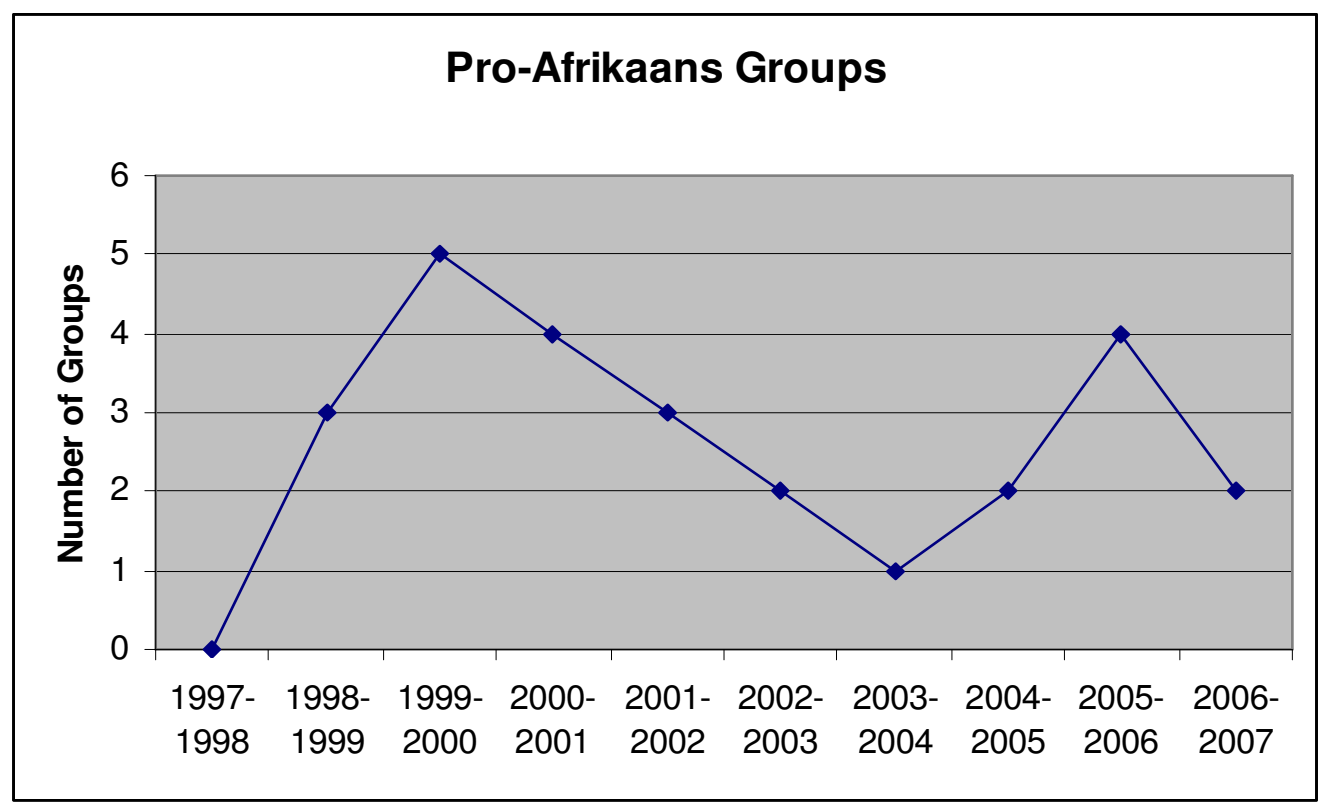

Figure 3. Pro-Afrikaans groups lodging complaints over the 10 year period

The analysis of pro-Afrikaans complaints contrasts significantly with both the graph for the overall number of Afrikaans complaints and the overall pattern of the whole data set in figure 1. This refutes the assumption that the number of pro-Afrikaans groups would have a significant impact on the overall number of complaints. If that were the case, we could expect the peak trends to tally across overall number of complaints and the number of groups complaining. The implication is that the bulk of complaints in favour of Afrikaans were lodged by individuals. Nonetheless, this pattern does not belittle group complaints, as generally a group complaint is thought to carry more weight than one made by individuals.

\section{Reasons for the decline in complaints to PanSALB by the Afrikaans speaking community}

\subsection{PanSALB's ineffectiveness}

The literature review, coupled with interviews with former complainants, made it clear that the decline in language rights violation complaints received by PanSALB can largely be attributed to PanSALB's real or perceived ineffectiveness in as far as the enforcement of recommendations following the investigation of language rights violation complaints is concerned. To quote Perry (2004: 521), "PanSALB ... fails to protect language rights, and, as a structure, serves to co-opt civil society and help make docile bodies of ordinary citizens". 


\subsection{Bottom-up language planning}

In as far as the Afrikaans speaking community is concerned, the findings of the Language Rights Monitor Project, a PanSALB initiated project in collaboration with the Unit for Language Management at the University of the Free State, point towards a tendency away from complaining to PanSALB (i.e., top-down language planning) towards bottom-up language planning, where various individuals and organisations take language planning activities upon themselves.

In an article based on the findings of the above-mentioned monitor project for the period 1 January to 31 December 2003, Truter and Lubbe (2007: 1) discuss cases of positive language planning as reported in the print media and conclude that a perception has been established in a large percentage of the general public in terms of which the principle of language equality is acknowledged but not consistently executed in practice - a state of affairs that gives preference to English to the detriment of all the minority or less dominant languages. $80 \%$ of all the cases of positive language planning reported in the media in the period under review should be regarded as bottom-up language planning, where various groups took it upon themselves to promote multilingualism by improving the status of a language or languages. According to Truter and Lubbe (2007: 16), language matters are not a priority to the state and discontent concerning perceived and actual instances of discrimination is rife. In Truter and Lubbe's (2007) overview of various instances of bottom-up language planning, it is encouraging to note that examples include positive steps with regard to African languages, for example (i) Absa's inclusion of these languages on its ATMs; (ii) Nokia's offering of four additional South African languages to its cell phone users; and (iii) Media24's decision to only consider books written in the African languages for its prestigious M-Net prize.

However, by far the majority (80\%) of cases of positive bottom-up language planning reported in the media concern Afrikaans. Afrikaans outnumbers the other languages both in terms of magnitude and support from its speakers. Examples of such bottom-up planning include:

- The dramatic expansion of Afrikaans printed media, whereby a number of new magazines in Afrikaans were launched. 
- The Bravo school project under the auspices of the Afrikaans daily Cape newspaper Die Burger and the Stigting vir bemagtiging deur Afrikaans (Foundation for Empowerment through Afrikaans).

- The collaborative effort of the then Rand Afrikaans University, the Gauteng Afrikaans daily newspaper Die Beeld and the ATKV (Afrikaans Language and Culture Organisation) to improve the skills of Afrikaans language teachers via the use of newspapers.

- The Rapport-onderwysfonds (teaching fund) of the Afrikaans weekly newspaper Rapport, the labour union Solidariteit (Solidarity) and the Afrikanerbond, which offers the opportunity to consolidate education through medium of Afrikaans, as well as Afrikaans as subject (the airline Sunair subsequently not only reinstated Afrikaans on its flights but also contributed to this fund).

- Various prizes including prizes for continued contribution to Afrikaans, literary prizes under the auspices of among others the ATKV, Rapport, Naspers, Sanlam and the Afrikaans national radio station Radio-Sonder-Grense (RSG).

- The L.W. Hiemstra trust that aims to promote the publication of Afrikaans non-fiction texts, such as dictionaries, books on language, literature, history, economy, religion, etc.

- The SATI translation prize.

- The Pendoring prize for original, creative advertising copy in Afrikaans, supported by Media24, RSG, the Afrikaans television channel kykNet, the publishing house Caxton, the Afrikaans life style magazine De Kat and the ATKV.

- The establishment of private Afrikaans radio and television stations.

- The Stellenbosse Woordfees (The Stellenbosch Word Festival).

- An increase in the number of mainly Afrikaans Arts festivals, such as the Suidoosterfees, the Klein Karoo Nasionale Kunstefees and Aardklop, as well as UKkasie, an Afrikaans Arts festival held in London with the sponsorship of $K W V$, $A T K V$ and the labour union $U A S A$.

From the above examples noted by Truter and Lubbe (2007: 18-22), it is clear that a shift has occurred away from top-down language planning to bottom-up language planning, and this shift is particularly evident in as far as Afrikaans is concerned. These findings are highly relevant to the decline which PanSALB is experiencing in the number of language rights 
violation complaints received. Since PanSALB's inception most of the complaints came from the Afrikaans speech community. The decline in complaints received from this community and the upsurge in bottom-up language planning, in particular as far as Afrikaans is concerned, indicates a loss of trust in the state's (and by implication PanSALB's) ability or willingness to act on language matters (cf. also Kriel 2003).

\subsection{The establishment of the NTLA and the NFA}

Up to now it has been argued that most of the language rights violations complaints to PanSALB came from the Afrikaans speech community, and emphasis was placed on the apparent change in strategy of this particular community, from lodging complaints with PanSALB to so-called "bottom-up" language planning. However, the role of another PanSALB structure, namely the National Language Bodies (NLBs), also needs to be considered in explaining the decline in language rights violation complaints received by PanSALB, in particular that of the Nasionale Taalliggaam vir Afrikaans (NTLA "National Language Body for Afrikaans").

PanSALB established the NLBs to advise on matters regarding any particular language. In March 2003 the executive of the NTLA came to the realisation that the NTLA was still-born due to a lack of funding. The NTLA felt that it was in no position to fulfil its mandate or to embark on the projects it had set itself as goals, and generally felt itself disempowered to the extent that some of the members of the executive committee resigned. Consequently an ultimatum was put to PanSALB: either the National Language Policy Framework (NLPF) should be implemented, or the NTLA should be given a mandate to develop a National Language Strategy for Afrikaans. In September 2005 the NTLA convened a meeting in consultation with the Federasie van Afrikaanse Kultuurorganisasies (FAK "Federation for Afrikaans Cultural Organisations") during which a gap in the functioning of the NTLA was acknowledged and the development of a National Language Strategy for Afrikaans was decided upon. A continuation committee, the Nasionale Forum vir Afrikaans (NFA "National Forum for Afrikaans"), was elected to look into strategies that would best serve the Afrikaansspeaking community and to conduct an Afrikaans Language Audit. Following this language audit in 2004, the NFA as sub-committee of the NTLA, under the auspices of PanSALB, convened an Afrikaans Language Summit in Stellenbosch in August 2004, with follow-up summits in Johannesburg in February 2005 and Pretoria in March 2007. 
The aim of these summits was to develop a language strategy for Afrikaans. The rationale for such a strategy is summarised by Prinsloo (2006:3):

Die Afrikaanse taalgemeenskap verkeer enersyds op verskeie terreine in hedendaagse Suid-Afrika onder sterk druk. Andersyds is daar groot uitdagings vir die Afrikaanstaliges met al hulle kundigheid, ervaring en goeie netwerke. Tydens die taalstrategiebespreking het dit telkemale duidelik na vore gekom dat by die Afrikaanstaliges ' $n$ wil en gereedheid is om aan ' $n$ strategie vir die toekoms te dink. In die voorgestelde srategiese raamwerk vir Afrikaans word selfs verwys na 'n beplanningsmodel om die taalverskuiwing in Afrikaans om te keer.

(On the one hand, the Afrikaans speech community finds itself subjected to strong pressure in different domains in South Africa. On the other hand, great challenges exist for speakers of Afrikaans with their knowledge, experience and good networks. During the language strategy discussion, it was repeatedly made clear that speakers of Afrikaans have the readiness and will to think about a strategy for the future. The suggested strategic framework for Afrikaans even refers to a planning model to reverse language shift in Afrikaans.)

The 2005 summit held in Johannesburg centred on the proposed strategic framework for Afrikaans. The proposed strategic framework states the values and points of reference, the preconditions to which such a strategy must adhere, the structure and management of the strategy, a SWOT analysis, a vision, a mission, goals, strategies for implementation, quality control and evaluation, and finances. At the conference it was decided that there were sufficient grounds for the process to continue and the proposed language plan was accepted. In essence this language plan endeavours to mobilise the Afrikaans speaking community around one single idea, namely a language plan for Afrikaans, with the NFA acting in a consolidating and coordinating capacity in fulfilling the following two tasks:

(i) updating and refining the Afrikaans Language Audit; and

(ii) creating forums for feed-back on Afrikaans. 
Following the 2005 summit, the book Op pad na 'n taalstrategie vir Afrikaans (Werkboek: Bespreking tydens die Afrikaanse Taalberaad van Augustus 2004, en opvolgwerk daarna, 2005 -'06 was published under the editorship of Karel Prinsloo. This publication contains all the papers read at the 2004 summit, the Language Strategy itself, as well as an updated version (February 2006) of all information received on Afrikaans language projects and activities. This extensive list gives a profile of the magnitude of organisations, projects, industries, unions, entertainment, bursaries, arts, culture, media (radio, television and publishers), literacy projects, language awareness groups, language courses, language tourism, language technology, translation, interpreting and editing services, welfare services, science and technology institutions, dictionary projects, book clubs and academic journals that mainly focus on Afrikaans or the Afrikaans speech community.

At the March 2007 summit held in Pretoria it was once more decided to use the language plan as the point of departure. However, it was also decided that an overarching Afrikaans Language Board (similar, for instance, to the Jewish Board of Representatives) should be established, and on 14 April 2007 a meeting was held in Stellenbosch where it was decided that such a Board would fall under the Commission for the Promotion and Protection of the Rights of Cultural, Religious and Linguistic Communities (the CRL Commission), as this Commission has the constitutional task of promoting and protecting the rights of linguistic communities.

The support for and interest in the Language Strategy (representing the broader Afrikaans sociolinguistic profile) points towards a perceived unsatisfactory language dispensation in as far as the Afrikaans speaking community is concerned. It is therefore unlikely that the decline in complaints received by PanSALB from this speech community is indicative of an acceptance of the status quo. Rather, it should be interpreted as a withdrawal of support for one PanSALB structure (i.e., Language Rights Monitoring) and the addition of support to another, i.e., the NFA and ultimately the envisaged Language Board under the auspices of the CRL Commission. In other words, this could be seen as a move away from claiming individual language rights towards supporting group language rights.

However, one should be cautious in attributing the decline in language rights violation complaints received by PanSALB to the establishment of the NFA. From the literature 
consulted, the most obvious reason for the decline relates directly to the perceived lack of success PanSALB has had in dealing with language rights violation complaints - if not in individual cases then most certainly in the eyes of the broader Afrikaans-speaking community. Without exception all the papers, comments and discussions at the three summits assume the "endangered / marginalised / reduced position" of Afrikaans as a point of departure and a decline in complaints must be viewed against this background. What is clear, though, is that there is a move away from lodging complaints with PanSALB toward involvement with other organisations who strive for the promotion of multilingualism and/or Afrikaans.

The point remains that language activism seems to be largely restricted to the Afrikaans speech communities. If this particular community with its social and financial capital has lost trust in the state's ability to act on language rights, it is unlikely that the speakers of the other indigenous languages would have success in mobilising support. As a case in point it should be noted that no other National Language Body has thus far been remotely as active as the NTLA and that, before the establishment of the NFA, the NTLA found itself incapacitated due to lack of funding. The current drive toward the establishment of the Language Board will ultimately place the NTLA alongside many other organisations who concern themselves with Afrikaans, but the watch-dog function will lie with the Afrikaans Language Board.

In August 2007, the NFA in collaboration with the CRL Commission initiated a call to all speakers of Afrikaans, Afrikaans speaking communities and organisations to assist in the registration of a body that will facilitate the concerns of Afrikaans and to make use of the opportunity created by the Constitution for the protection of language, cultural and religious rights (section 185) in South Africa. Consequently all Afrikaans orientated communities and organisations were requested to register with the CRL Commission before the $31^{\text {st }}$ of August 2007. If this initiative is successful, and if the envisaged Board materialises, it will be the first of its kind As far as could be ascertained no other language groups are currently involved in a similar process - a fact that once more may point to the need for awareness campaigns.

However, following the call by the NFA and CRL, a review committee headed by Prof. Kader Asmal which investigated the Chapter 9 institutions, namely the Public Protector, the SA Human Rights Commission, the CRL Commission, the Commission for Gender Equality, the 
Auditor-General and the Electoral Commission, tabled a report in the National Assembly on 21 August 2007. This report recommended that -

The Committee, recognising that all human rights are interdependent and that the mainstreaming of specific human rights may bring them to the forefront of the field, came to the conclusion that the Gender Equality Commission, the Youth Commission, the South African Human Rights Commission, and the Commission for the Promotion and Protection of the Rights of Cultural, Religious and Linguistic Communities (together with PanSALB) be collapsed into one super-institution called the South African Commission for Human Rights and Equality.

(Seedat and Wall 2007: 3,4)

The reasoning behind their recommendation included (i) avoiding duplication of work amongst the currently-operational institutions, (ii) increasing administrative efficiency, (iii) enhancing public accessibility, (iv) pooling capacity and resources, and (v) facilitating interaction with Parliament. In the words of the report -

a single organisation will be a strong and authoritative champion for equality and human rights. The new body will incorporate the expertise on specific areas of human rights, now spread across bodies, and will thus be better able to respond to the myriad human rights challenges in South Africa.

(Seedat and Wall 2007: 3,4)

As the new structure has not been established as yet, it is almost impossible to comment on the future of language rights violation complaints in South Africa.

\section{Conclusion}

The largest number of language rights violation complaints received by PanSALB came from the Afrikaans speech community. PanSALB's failure in satisfying these complainants has led to a loss of trust in the organisation and concomitant scepticism towards top-down language planning. As a result, a strong tendency towards bottom-up language planning is observed. 
Yet a positive outcome for the efforts of the Afrikaans community remains uncertain in light of the recommendation by the Parliamentary review committee to collapse the various Chapter 9 institutions (including the CRL Commission and PanSALB) into the South African Commission for Human Rights and Equality. There is no guarantee that the envisaged Afrikaans Language Board will be incorporated into the new "super-institution".

\section{References}

Kriel, M. 2003. Discourses of language activism: The Green Movement and Afrikaans. Language Matters 34: 48-55.

Lubbe, J. and E. Truter. 2007. Gevalle van positiewe taalbeplanning soos gerapporteer in die gedrukte media. Southern African Linguistics and Applied Language Studies 25(4): 557-574.

Perry, T. 2004. The case of the toothless watchdog: Language rights and ethnic mobilization in South Africa. Ethnicities 2004(4): 501-521.

Prinsloo, K (ed). 2006. Op pad na 'n taalstrategie vir Afrikaans. Nasionale Forum vir Afrikaans: Pretoria

Seedat, S and A.J. Wall. 2007. The parliamentary review of institutions supporting democracy in South Africa. IDASA. 